Mem. Inst. Oswaldo Cruz, Rio de Janeiro, Suppl. Vol. 79 :85-91, 1984

\title{
ACUTE CHAGAS' DISEASE
}

\author{
JOĀO CARLOS PINTO DIAS
}

\section{History and general considerations}

Carlos Chagas described in classical works the clinical, parasitological and anatomopathologic elements of the acute phase of American trypanosomiasis as early as he took his first contacts with the disease (Chagas, 1909, 1910, 1916a, b). In the years 30 Mazza (1937) called attention to the endemy, studying hundreds of acu te cases in Argentina, and Romaña's (1935) description of the "eye sign" was the basic factor that allowed the discovery of many acute patients in Argentina, Uruguay and Brazil (Romaña, 1935; Talice et al. 1940; Martins, Versiani \& Tupinambá, 1940). Chagas' concepts were then took over by E. Dias and his group in Bambuí (Brazil) that systematize the general clinical picture of the acute disease, its diagnosis and epidemiological elements (Dias, Laranja \& Nobrega, 1946; Laranja et al., 1956). Other important contributions on the subject appeared later, with Amato Neto (1958), Bocca Tourrés (1972), Lugones (1962), Ferreira (1968) and Rassi \& Carneiro (1968).

Acute Chagas' disease is characterized by high parasitemia, short clinical course and acute inflammatory reactions in the parasite harboring tissues. Besides their epidemiological significance, acute cases are very important because of the mortality in young children and the present possibility of cure with specific drugs. The transmission of Trypanosoma (Schizotripanum) cruzi (T. cruzi) by vectors is still the most important mechanism of human infection in the endemic areas, but blood transfusion and also congenital transmissions are also playing significant role (Dias, 1979). Excepcional transmission mechanisms such as through kidney transplantation and maternal milk have also been recently described in Brazil (Dias, 1984a).

Human cases of acute Chagas' disease never were very numerous, even in endemic regions, in contrast with the number of chronic cases (Chagas, 1916a). In Brazilian hyperendemic areas such as Bambuí, Goiás and Triângulo Mineiro acute cases virtually desappeared after effective insecticide spraying (Dias, 1984 a). It seems that the most detectable cases occur among lower age groups because of high vectorial transmission pressure, as it will be discussed later on (Dias, 1982).

Medical bibliography about acute Chagas' disease is becoming more and more scarce in the two last decades. According to Cançado (1981), the short duration of this phase and the lack of diagnosis are the two main reasons for the apparent rareness of acute cases in endemic countries. Besides the problem of "inaparent" acute Chagas' disease (Teixeira, 1977), in several times the physician does not think in acute Chagas' disease and, when he does, frequently he does not know what appropriate diagnosis method must be used (Cançado, 1981).

Perhaps the in terest evaluated by published reports about acute Chagas' disease might be decreasing because the basic clinical and epidemiological works are already well stablished. Moreover, the form tends to desappear chiefly in the regions where a good research can be made. Even so some advances have been reached in the last years and will be object of the present chapter.

Another basic question concerns to the clinical outcome of the "acute" patients, at long term. Would be the patients who had typical acute forms a special group with a particular evolutive pattern? Some recent publicated longitudinal stu dies will be also considered here, about this problem.

Clinical description does not constitute an essential part of the present revision, but as some particular points were considered in recent works they will be mentioned. Moreover, as a general support about the human disease, some experimental works will be mentioned, although they belong to other parts of the present Symposium.

\section{Epidemiollgy}

As mentioned above, exceptional cases of $T$. cruzi transmission throughout maternal milk and kidney transplantation were recently reported. The possibility of transmission by the sexual act was also discussed by Jörg et al. (1972) in Argentina when they found viable parasites in menstrual liquid of infected women. Congenital and transfusional transmission are becoming increasingly important in endemic countries, and must be object of specific considerations in this Symposium. It was recently estimated that in Brazil nowadays about 15,000 new cases per year can occur by transfusional transmission and 7,500 by congenital route (Dias, 1984a). The detection of acute autoctonous cases in Amazonia has epidemiological significance, since they could indicate housing colonization by wild infected triatomines like Panstrongylus geniculatus, as it is being observed in other Brazilian areas (Silveira \& Sakamoto, 1983). Two enigmatic outbreakes of acute Chagas' disease were described in Brazil. In Teutonia, Rio Grande do Sul state, 17 people became infected with the occurence 6 fatal cases, in the absence of triatomines and other "conven- 
tional" transmission possibilities. The main hypothesis was oral transmission (from food contamination with marsupials infected urine) (Dias, 1979) but is was also supposed the possibility of chronic disease "re-acutization" because of massive corticoide administration (Di Primio, 1971). The other episode occurred in Belém, Pará, with three acute cases in the same family, that possibly could be infected through the ingestion of food contaminated with triatomine feces (Dias, 1979).

As already mentioned, vectorial transmission is becoming more rare in insecticide sprayed areas. In Brazil important foci of Chagas' disease transmission persist in untreated areas of the states of Minas Gerais, Goiás and Bahia, where Triatoma infestans was recently introduced (Dias, 1984 a). Transmission is still very high in certain areas, such as Santiago del Estero, Argentina, which has accumulated the largest number of reported acute cases (over 6,000 patients), despite the existence of local control programs (Ledesma et al., 1984).

Reviewing the vectorial transmission in an endemic area, Dias (1982) stablished a very close correlation between the transmission pressure, incidence of acute cases and their clinical pattern. Underneath high pressure (determined by high degrees of colonizated dwelling with high densities of infected bugs), the Bambuí region presented high incidence of low age acute cases, with high clinical severity and mortality. Following insecticide spraying, the number of infected houses decreased progressively in that area until the level of $5 \%$, in which human transmission was interrupted. With the beginning of the control program, acute cases became more and more rare, and the severe low-age cases disappeared. It seems that owing to the decrease in the transmission much more time is necessary to induce infection in exposed people, confirming the pioneer Dias (1945) and Pellegrino (1953) field observations as well as Rossell (1976) and Rabinovich \& Rossell (1975) mathematical models. An estimate of acute cases detection in this area was also calculated for the pre-prophilatical period, indicating that the possibility was to detect one "apparent" acute case among five that actually occurred $(20 \%)$; for the $0-2$ years age group this correlation was 1:3. If one would consider the correlation among detected acute cases and the general incidence of Chagas' disease in that time and area, the proportion would be about $1: 14$. The calculated transmission risks were then of about $2.7 \%$ per year for the total rural population and of about $5 \%$ for the $0-10$ age group (Dias, 1982).

\section{Clinical picture, morbidity and mortality}

In a general way, the recent descriptions of acute cases agree completely with the classical sorks (reviewed by Dias, 1982). It has be:n stressed that in transfusional transmission the incubation period is usually longer than in the vector-transmitted cases, reaching until 4 or 5 months (Cançado, 1981). The congenital transmission has been usually associated with prematurity and birth mortality (Bittencourt, 1984, this Symposium), but in Argentina Moya (1984) recently detected several completely asymptomatic cases.

The 'innaparent' form of acute Chagas' disease was described by Teixeira (1977) some years ago. Her prospective studies in an endemic brazilian area, with specific serology for Chagas' disease being performed in healthy people, showed that 9 among 14 detected cases exhibited a so discrete clinical picture that they probably would not seek medical care. It was noticed that fever and parasitemia were lower in these "innaparent" than in the symptomatic acute cases, but some of them had lymphodes and heart involvement. Later on, Teixeira (1981) reported that cellular immunity was depressed in the "innaparent" group, specifically for cutaneous test made with $T$. cruzi antigens. In Santiago del Estero (Argentina hyperendemic area) studies are showing that about $90 \%$ of the acute cases are likely to be innaparent or, at least, are not detected in the medical care system (Ledesma et al., 1984).

Reviewing 313 acute cases in Bambuí, MG, Brazil, Dias (1982) stressed the higher severity of the acute clinical pictures in younger age groups, chiefly in $0-2$ years. All of these cases presented fever, to a certain extent correlated to parasitemia levels. Portal of entry were present in $77.4 \%$ of the cases, mainly Romaña's sign $(49.5 \%)$, without correlations to sex or age groups. Heart involvement of variable degree probably occurs in almost every case, as stressed by Laranja et al. (1956) and Rassi (1979). The chest X-ray detected $87.1 \%$ of cardiac enlargement, demonstrating to be a very sensible diagnostic method in the study of heart acute disease. The problem is that in several times cardiac enlargement is very slight, being only detected after two or more examinations of different days (weeks) (Dias, 1982). Electrocardiographical abnormalities were more evident among younger patients, wich presented also more evident signs of heart failure (Laranja et al., 1956).

In the Bambui study some rare clinical pictures called attention such as the slight and transitory thyroid enlargement ( $7 \%$ of the cases) without apparent disturbance of the gland. Four patients displayed early dysphagia in the acute phase, that disappeared at the ending of the febrile period. The involvement of the nervous system in the acute phase may be very frequent, even in oligo or asymptomatic cases. In the Bambui group of patients some general neurologic symptoms such as irritability, sleepiness and transitory convultions could be observed in some younger patients without meningoencephalitis signs. (Dias, 1982). In this connexion it is very significant the isolation of $T$. cruzi trypomastigotes from the liquor in 8 out of 11 acute patients in the absence of neurological symptomatology (Hoff et al., 1978). Several clinic and experimental works demonstrated the existence of different degrees of involvement in central, peripheric or authonomic nervous system in acute Chagas' disease (Andrade \& Andrade, 1979). 
Neuronal destruction seems to be much more intense in the acute than in chronic phase. According to Tafuri (1974) it is an universal and unpredictable phenomenon. Acute desnervation is often not sufficient to produce clinical symptoms because of the high functional tolerance limit of affected organs. Oesophagus, for instance, has a tolerance for about $80 \%$ desnervation and so are very rare dysphagias in acute cases (Koberle, 1979). Late symptoms emerge with progressive desnervation caused by chronic factors and the physiological neuron destruction (Oliveira, 1979). In peripheric nervous system, electromyographic registers also shows very precocious neurones destruction in acute phase, with consequent degeneration of the nerves (De Faria, 1984). The neurologic recovery was experimentally studied by Machado \& Machado (1979) that showed secondary axon reinervation of affected territories and also the functional recuperation of partially injuried neurones.

The neuronal destruction mechanism still remains obscure, probably different pathogenic factors being involved. About central nervous system it is worth to mention some minima neurologic syndroms described by Jörg et al. (1972) and also Girardelli (1969) in young patients in the acute period. Argentine works are reporting intracranial calcifications in about $28 \%$ of congenital cases. These calcifications are present chiefly in the frontal region of the brain and seem to induce late intelectual disturbs (Moya, 1984).

In the natural history of Chagas' disease, the role of different evolutive factors has been studied in patients or experimentaly. Among them may have importance the $T$. cruzi intraspecific variation (different strains), the nature of the inflamatory process, the immune pathogenetical mechanisms, the reinfections and several factors related to the vertebrate host (age, sex, race, nutritional status, intercurrent diseases, etc). It seems that in the acute phase are very important the factors directly related to the parasite action and to the acute inflamatory reaction (Schlemper $\mathrm{Jr}_{\text {. }}, 1982$ ). Autoimmune mechanisms and the fibrotic lesions will be much more evident and important in the chronic phase (Tafuri, 1974). In mice, Schlemper $\mathrm{Jr}$. (1982) showed a very close relation between the intensity of the acute inflamatory process and the late development of fibrosis.

Reinfection is possible in experimental models, but its role in the clinical course of Chagas' disease is not yet well stablished (Brener, 1979). There are two registered cases of a new acute phase in chronic chagasic patients but they most constitute an exception (Dias, 1982). In Argentina, Ledesma et al. (1984) has sometimes observed new acute phase in young patients whose first acute Chagas' disease was cured by chemotherapy but that returned to endemic areas.

The clinical evolution of 313 acute patients in Bambui was followed in longitudinal studies (Dias, 1982). As mentioned above the most severe acute pictures occurred among the patients bellow 2 years age, chiefly in relation to heart involvement, hepatosplenomegaly, neurological disturbances and mortality. In general, acute heart disease recovery occurred from 3 to 6 months after the fever disappearing in the nontreated and non-fatal cases. Nevertheless, the X-ray picture sometimes needed more than 3 years to normalize. In other cases, EKG findings in the acute period such as 1 st degree A.V block and T-wave primary changes could be observed for many years more, sometimes disappearing and appearing again in subsequent registers of the same patient (electrocardiographical "mutability"). Ventricular extrasystoles and complete intraventricular bundle branch blocks were very rare in the acute cases of Bambuí. Both these EKG disturbances, as well as the low-voltage QRS pattern in the frontal plan have very bad prognosis. The long term observations of the Bambui patients (follow-up of about 30 years) showed three main informations (Dias, 1982):

a) The prevalence of EKG alterations at the chronic phase is significantly higher in the patients who displayed abnormal EKGs at the acute phase than in those who had normal tracings in this early stage of the disease.

b) The prevalence of digestive forms among patients that had a more severe acute phase was significantly higher than in those in which the acute picture has been more benign.

c) The major tendence to present abnormal EKGs in the patients whose acute phase occurred in lower ages ( 0 - 2 years) than in older patients.

Mortality is always correlated with lower age groups, in acute Chagas' disease (Chagas, 1916 b; Ferreira, 1968). Table I shows the mortality pattern in the Bambuí study.

TABLE I

Mortality of acute Chagas' disease according to age groups, in Bambuí, Brazil (Dias, 1982)

\begin{tabular}{|c|c|c|c|}
\hline \multirow{2}{*}{ Age groups (years) } & \multicolumn{2}{|c|}{ No of cases } & \multirow{2}{*}{$\%$ mortality } \\
\hline & examined & deaths & \\
\hline $\begin{array}{c}0-2 \\
3-5 \\
6-10 \\
11 \text { and more }\end{array}$ & $\begin{array}{l}86 \\
89 \\
86 \\
52\end{array}$ & $\begin{array}{r}17 \\
6 \\
3 \\
0\end{array}$ & $\begin{array}{r}19.8 \\
6.7 \\
3.5 \\
0.0\end{array}$ \\
\hline Total & 313 & 26 & 8.3 \\
\hline
\end{tabular}


In untreated fatal cases, dead followed severe cardiac involvement and/or chagasic meningoencephalitis, chiefly in the first month of the disease. Sometimes intercurrent factors such as measles and pneumonia can precipitate the death. Electrocardiographical pattern of fatal acute disease was well stablished by Laranja et al. (1956): myocardial damage was detected by the EKG in $85.7 \%$ of the fatal group, against $37.7 \%$ of the non.fatal patients. In all of the fatal cases clinical findings were more evident, if any age. Conversely to what happens at the chronic phase, no sex related differences have been observed in mortality, in acute Chagas' disease (Dias, 1984a). About the races, the Bambui study revealed significant major proportion of deaths among negros than in white patients (Table II).

TABLE II

Mortality and race in acute Chagas' disease in Bambui, Brazil, in the age group $0-7$ years (Dias, 1982)

\begin{tabular}{l|rr|r|r}
\hline \multirow{2}{*}{ Race } & \multicolumn{2}{|c|}{ Evolution } & \multirow{2}{*}{ Total } & Mortality (\%) \\
\cline { 2 - 3 } & Fatal & Non-fatal & & \\
\hline White & 17 & 168 & 185 & 9.2 \\
Mulato & 5 & 33 & 38 & 13.2 \\
Negro & 4 & 8 & 12 & 33.3 \\
\hline Total & 26 & 209 & 235 & 11.1 \\
\hline
\end{tabular}

$\mathrm{X}^{2}=6.254(\mathrm{~V}=2) ; \mathrm{p}=0.05 ;($ for white $\mathrm{X}$ mulato $\mathrm{p}=0.25)$

Another significant correlation in Bambuí material was found between mortality and absence of portal of entry signs: mortality was more frequent among the acute cases without apparent "chagomas", independent of the age. It seems that the defensive inespecific role of cell immunity could be very important against the parasite in the acute phase (Teixeira, 1981). The "chagomas" absence could represent a true lacking of this "first step" on the cellular delayed immunity response. About this matter it is being suggested that the major resistance of adult people to acute Chagas' disease could depend on the different kinds of immune defenses chiefly the phagocytosis and cellular lysis of the parasite by monocytic circulant cells (Andrade \& Andrade, 1979).

It is also important to note that with the introduction of specific chemotherapy, mortality in acute Chagas' disease is increasingly decreasing. Both in experimental and human observations it has been proved that precocious and adequate treatment generally is able to reduce parasitemia and to prevent the death (Cançado \& Brener, 1979).

\section{Diagnosis}

Direct blood examination still remains as the simplest laboratory technique for the parasitological diagnosis of acute cases. In the Bambui experience, the direct fresh method resulted positive in 303 out of 369 acute cases $(82.1 \%$ ), but sometimes this direct technique must be repeated for many times ( 3 to $8 /$ week) to detect the parasite (Dias, 1982). Some variations of this method have being tested by different authors. Among them, the most usefull and sensible technique seems to be the Strout method, very commonly used in Argentina, being based on the doble serum centrifugation after the natural clot retraction (Segura et al., 1981). Table III shows a comparision of some direct tests in Chagas' disease.

La Fuente (1983) has recently improved in Bolivia another test, utilizing blood centrifugation in micro-hematocrit capillar tubes. The tubes can be directly examined in microscope, and the parasites are seen in the leucocyte layer. The method is simple and requires smaller blood amount than in Strout technique; the results seem to be the same in both methods.

Xenodiagnosis and hemoculture are very sensible indirect methods in the acute phase. Liquid $\mathrm{LIT}^{*}$ medium is demonstrating to be very adequate to $T$. cruzi cultivation (Chiari et al., 1979). Nevertheless, xenodiagnosis is still the most utilized "indirect" method, the excellent performance in acute phase (see Table III). For acute patients it has been demonstrated that xenodiagnosis can be examined precociously, already showing high positiveness degrees two weeks after the insects feeding (Dias, 1982).

Besides the clinical picture, epidemiological data and some laboratory informations can help in the diagnosis acute Chagas. Among these data, several works indicate the finding of moderate leucocytosis plus important lymphocytosis as indicative of acute American trypanosomiasis (Cançado, 1981). Also are suggestive high titers of heterophilic antibodies in sera of febrile patients (Camargo \& Takeda, 1979). Pannuti et al. (1983) studied some tests ${ }^{*}$ in acute patients, detecting few false-positive results in all of them. The Authors insisted on the point that the quantitative micromethod test should always be followed by the absorption with beef cells, so that infections mononucleosis can be ruled out. Vattuone \& Yanowisky (1971) showed that when high positive titers of direct agglutination test decrease four or more times after sera adsorption with 2-Mercapto-Ethanol, acute Chagas' disease is strongly suggested.

* LIT $=$ Liver infuse tryptose.

" *Paul-Bunnell-Davidshon, Haff-Bauer, "Monospot" and micromethod tests. 
TABELA III

Comparative study of parasitological methods in 21 patients with acute Chagas' disease*

\begin{tabular}{l|r|r}
\hline \multirow{2}{*}{\multicolumn{1}{c}{ Method }} & \multicolumn{2}{c}{ Positiveness } \\
\cline { 2 - 3 } & No & $\%$ \\
\hline Fresh direct & 11 & 52.4 \\
Fixed drop & 10 & 47.6 \\
Triple centrifugation & 15 & 71.4 \\
Strout & 20 & 95.2 \\
Silicone filtration & 15 & 71.4 \\
Differencial Ly sis (Deane) & 4 & 19.0 \\
Xenodiagnosis** & 21 & 100.0 \\
\hline
\end{tabular}

* Apud Cerisola et al. (1972)

* Referencial test, utilizing 40 nymphs of $T$. infestons/patient

Immunological diagnosis has been improved in acute disease with the development of many techniques: the above mentioned agglutination test, the detection of Immune globulins $M$ with specific immunefluorescent conjugates and the circulating immunocomplexes research. Specific IgM detection is very sensible and precocious in acute Chagas' disease, being utilized in cogenital cases research (Camargo \& Takeda, 1979). In the acute phase it seems that the more precocious IgG tests are those that utilize membrane or flagellum antigens (Segura et al., 1981). The latex method also can be usefull since Teixeira (1977) verified a characteristic very quick reaction of this test in acute disease.

Circulant immunecomplexes (IC) seem to be very precocious and specific in acute Chagas' disease. Martin et al. (1984) verified in human cases sera that the antibodies present in IC belong to the IgM class and have high specificity to soluble and mitochondrial fractions of $T$. cruzi. Studying 28 acute cases, Freilij et al. (1984) could compare traditional IgM (immunefluorescence technique) with IC research (by ELISA method), observing that some times the apparent absence of IgM antibodies in acute cases is due to IC formation ("pre-serologic period"). The IC might be formed from multiple and different antigens which are resultant of a very intensive parasitary destruction. The general serologic profile in the first month of acute phase represents a classical primary immune response, that seems to be independent of the strain or entry route of the parasite (Martin et al., 1984).

For practical purposes, in endemic areas and health services, in front of a clinical suspicion, direct parasitological methods must be performed at least in four or five different days during the febrile period; serum collection in the first observation provide material for Strout method and general serology (IgG techniques; IgM if possible). If avaiable, xenodiagnosis and/or other "indirect" methods also could be performed, with precocious examination (14 to 21 days). Being negatives the results in this first approach, serology must be repeated 30 and 60 days later when, a serological convertion generally indicates an acute disease occurrence (Dias, 1984b). In the case of congenital disease the passive IgG transference from mother to child must be taken in account, being necessary to insist in the parasitological methods, in the IgM research and in a serological IgG follow up until 6 or 7 months of age (Segura et al., 1981).

\section{Treatment of acute Chagas' disease}

Specific treatment of Chagas' disease is being subject of other revision, in the present Symposium. However, some particular approaches on the acute disease management will be made here in short.

a) Both avaiable drugs Nifurtimox or Benzonidazole are effective in acute phase, in which specific treatment has its basic indication. The results can vary according the parasite strain. The best schedule is the continuous treatment during 60 days. Cure criteria must take in account that serologic and parasitological tests must become permanently negatives (Cançado \& Brener, 1979).

b) In extremely severe cases of acute myocarditis and/or of meningoencephalitis, corticoid may be employed ensembled to specific drugs, in order to decrease massive inflammatory reactions (Andrade \& Macedo, 1973).

c) Early treatment of accidental infections and chemoprophylaxis of $T$. cruzi transmission in kidney transplantation have been carried out in some centers (Dias, Brener \& Macedo, 1984). According to Brener (1984), 45 cases of accidental Chagas' disease in research laboratories or Health Services have been reported, being the cases distributed among Argentina, Austria, Brazil, Chile, Colombia, England, France, Germany, Panama, United States and Venezuela. In the cases of accidents, Brener (1984) suggests that once treatment starts very early (in the same day of in the day after the accident) the presumptive infection is aborted. Generally, a short term treatment of 8 to 10 days employing the active avaiable drugs is able to prevent the development of the parasitism, being usually very well tolerated. The same idea was recently applied in a kidney transplantation case with infected donnor, consisting in the specific treatment of the donnor during 10 days before the surgery (to decrease the parasitism) and of the recipient during 10 days 
after the surgery. The tolerance was very good for both the patients and the parasitological and serological follow-up of the receiver in the next 6 months has not demonstrate the parasite transmission (Dias, Brener \& Macedo, 1984).

\section{ACKNOWLEDGEMENTS}

We are gratefull to Prof. Zigman Brener, for his precious help in the revision of this text.

\section{REFERENCES}

AMATO NETO, V., 1958. Contribuiçâa ao conhecimento da forma aguda da doença de Chagas. Tese. Fac. Med. Univ. São Paulo, 332 pp.

ANDRADE, Z. \& ANDRADE, S.G., 1979. Patologia. In: Brener, Z. \& Andrade, Z. Trypanosoma cruzi e Doença de Chagas. Guanabara Koogan Ed., Rio de Janeiro: 199-248.

ANDRADE, S.G. \& MACEDO, V.O., 1973. Tratamento combinado da Doença de Chagas com Bayer 2502 e corticoide. (Estudo experimental e clínico). Rev. Inst. Med. trop. Säo Paulo, $15: 421-430$.

BOCCA TOURRÉS, C., 1972. Enfermedad de Chagas. Clínica de la fase aguda. An. Simp. Intern. Enf. Chagas (Buenos Aires, Argentina): $227-231$.

BRENER, Z., 1979. O parasito: relaçōes hospedeiro-parasito. In: Brener, Z. \& Andrade, Z. Trypanosoma cruzi e Doença de Chagas. Guanabara Koogan Ed. Rio de Janeiro: 1-41.

BRENER, Z., 1984. Laboratory acquired Chagas' disease: an endemic disease among parasitologists? In: Genes and antigenes of parasites: a laboratory manual. Carlos Morel (Ed.), $2^{\text {nd }}$ Ed., Rio de Janeiro: Fundação Oswaldo Cruz (1 v.) $: 3-10$.

CAMARGO, M.E. \& TAKEDA, G.K.F., 1979. Diagnóstico de laboratório. In: Brener, Z. \& Andrade, Z. Trypanosoma cruzi e Doen ça de Chagas. Guanabara Koogan Ed., Rio de Janeiro: 175-198.

CANÇADO, J.R., 1981. Forma aguda da doença de Chagas. In: Modernos conhecimentos sobre doença de Chagas. (L. Decourt \& O.M. Campos, coord.). Acad. Mineira Med., 308 pp.

CANCADO, J.R. \& BRENER, Z., 1979. Terapêutica. In: Brener, Z. \& Andrade, Z. Trypanosoma cruzi e doença de Chagas. Guanabara Koogan Ed., R.J.: 362-424.

CERISOLA, J.A.; RUSSO, M.C.; PRADO, C.; YOZAMI, L.B.J.; ROHWEDER, R.W.. 1972. Estudio comparativo de diversos métodos parasitológicos en la enfermedad de Chagas aguda. An. Simp. Intern. Enf. Chagas, Bucnos Aires (1v):97$100,1972$.

CHAGAS, C., 1909. Nova tripanozomiaze humana. Estudos sobre a morfologia e o ciclo evolutivo do Schizotrypanum cruzi n. gen., n. sp., ajente etiolojico de nova entidade morbida do homem. Mem. Inst. Oswaldo Cruz, 1 :159-218.

CHAGAS, C., 1910. Aspecto clínico geral da nova entidade mórbida produzida pelo Schizotrypanum cruzi. Brasil Médico, $27: 1-6$.

CHAGAS, C., 1916a. Trypanosomiase americana : forma aguda da moléstia. Mem. Inst. Oswaldo Cruz, 8 :37-65.

CHAGAS, C., 1916b. Pathogenic processes of american trypanosomiasis. Mem. Inst. Oswaldo Cruz, $8: 3-38$.

CHIARI, E.; DIAS, J.C.P.; LANA, M. \& CHIARI, C.A., 1979. Hemocultures for the parasitological diagnosis of human Chagas' disease in the chronic phase. An. Congr, Intern. D. Chagas (Rio de Janeiro): N-1 - N-5.

DE FARIA, C.R., 1984. Desnervação motora na doença de Chagas. Workshop on longitudinal studies in Chagas' disease. Salvador, Bahia, CNPq/TDR (UNDP-WB-WHO). In press.

DIAS, E., 1945. Um ensaio de profilaxia de moléstia de Chagas. MES/IOC, Imprensa Nacional (Rio de Janeiro), 116 pp..

DIAS, E.; LARANJA, F.S. \& NÖBREGA, G., 1946. Doença de Chagas. Mem. Inst. Oswaldo Cruz, $43: 495-582$

DIAS, J.C.P., 1979. Mecanismos de Transmissão. In: Brener, Z. \& Andrade, Z. Trypanosoma cruzi e Doença de Chagas. Guanabara Koogan Fd., Rio de Janeiro :152.174.

DIAS, J.C.P., 1982. Doença de Chagas em Bambui, Minas Gerais, Brasil. Estudo clínica-epidemiológico a partir da fase aguda, entre 1940 e 1982 . Tese. Fac. Med. da Univ. Fed. Minas Gerais, Belo Horizonte, 376 pp.

DIAS, J.C.P., 1984a. Epidemiology of Chagas' disease in Brazil. In: Brenner, R.R. \& Stoka, A.M. Chagas' disease vectors. In press, 1984.

DIAS, J.C.P., 1984b. História natural da cardiopatia chagásica. In: Cançado, J.R. \& Chuster, M. Cardiopatia Chagásica. Fundaçãa Carlos Chagas, Belo Horizonte. In press.

DIAS, J.C.P.; BRENER, Z. \& MACEDO, M.A. 1984. Quimioprofilaxia da doença de Chagas em transplante renal com doador infectado. Rev. Soc. Bras. Med. Trop. 17 (Suplemento) :32.

DI PRIMIO, R., 1971. Erros e deficiências no diagnóstico da doença de Chagas no Rio Grande do Sul. O problema da provável contaminação por via oral do Trypanosoma cruzi em Teutônia, R.S.. O Hospital, 80:150-165.

FERREIRA, H.O., 1968. Forma aguda da doença de Chagas. In: Cançado, J.R. Doença de Chagas. Imprensa Oficial Minas Gerais : $359-373$.

FREILIJ, H.; CORRAL, R.; MONTEMAYOR, A.; LEDESMA, O.; BARBIERI, G. \& GRINATEIN, S., 1984. Deteccion de complejos inmunes circulantes formados por IgM en pacientes con infección aguda por T. cruzi. An. Reun. Enf. Chagas, Córdoba, Argentina. Soc. Arg. Protozool. :ID 13.

HOFF, R.; TEIXEIRA, R.S.; CARVALHO, J. \& MOTT, K.E., 1978. Trypanosoma cruzi in the cerebrospinal fluid during acute Chagas' disease. New Engl. J. Med., $298: 604-606$.

GIRARDELLI, M.A., 1969. Evolución electroencefalográfica em ninõs y adultos jovenes con infección chagásica crónica tratados con Bay 2502. Bol. Chileno Parasitol., $24: 35-38$. 
JÖRG, M.E.: BUSTAMENTE, A.: PELTIER, Y: FREIRE, R.S.: FIGUEIREDO. R.: OLIVA. R. \& ORLANDO. A.. 1972. Disfunción cerebral mínima como secuela de meningoencefalitis aguda por Trypanosoma cruzi. Prensa Med. Argent., $59: 1658-1669$.

KÖBERLE, F., 1979. Patologia da forma digestiva. An. Cong. Intern. D. Chagas (Rio de Janeiro) :K-1 - K-4.

LA FUENTE, C., 1983. Estudio longitudinal de la enfermedad de Chagas en Vallegrande, Santa Cruz, Bolivia. Workpaper. Meeting on longitudinal epidemiological studies on Chagas' disease. TDR (UNDP-WB-WHO)/FIOCRUZ, Rio de Janejro (Epicha 5), 5 pp..

LARANJA, F.S.; DIAS, E.; NŌBREGA, G. \& MIRANDA, A., 1956. Chagas' disease. A clinical, epidemiologic and pathologic study. Circulation, $14: 1035-1060$.

LEDESMA, O.: KALALO, E.; ROSALÉN, M.; LUGONES, H.; PERALTA. F.; FRAN. J.; ANELLI, C.M.; ALVAREZ, M. \& MOLINA, J., 1984. 36 casos de Chagas aguda.Formas de comienzo y sintomas al ingresar al servicio. An. Congr. Arg. Protozool. y Reunión Enf. Chagas, Córdoba (Argentina) :C7.

LLGONES, H., 1962. Consideraciones acerca de los sintomas del periodo agudo de la enfermedad de Chagas en la infancia. An. Congr. Intern. D. Chagas (Rio de Janeiro), 3 :361-870.

MACHADO, A.B.M. \& MACHADO, C.R.S., 1979. Cardiac reinnervation during the chronic phase of experimental Chagas' disease. An. Congr. Intern. D. Chagas (Rio de Janeiro) :R-1 - R-5

MARTIN, U.; MARDONA, C.; FERNANDEZ, H.; MARTELEUR, A. \& SUBIAS, E., 1984. Anticuerpos específicos anti Trypanosoma cruzi en niños con enfermedad de Chagas aguda. An. Reun. Enf. Chagas, Córdoba (Argentina). Soc. Arg. Protozool. :C6.

MARTINS, A.V.; VERSIANI, V. \& TUPINAMBÄ, A.A., 1940. Sobre 25 casos agudos de moléstia de Chagas observados em Minas Gerais, Mem. Inst. Ezequiel Dias, 3-4:1-66.

MAZZA, S., 1937. Nota a propósito de 240 casos de formas agudas de enfermedad de Chagas comprobadas en el pais por la M.E.P.R.A. La Prensa Med. Argent.

MOYA, P., 1984. Enfermedad de Chagas congénita. Experiencia clínica. An. Congr. Argent. Protozool. y Reun. Enf. Chagas, Córdoba (Argentina) :MR-1A.

OlivelrA, J.S.M. 1979. A fisiopatologia da moléstia de Chagas. An. Simp. Moléstia de Chagas. Publ. Acad. Cienc. Est. S. Paulo, $16: 82-95$.

PANNUTI, C.S.; ÂNGELO, M.J.O.: AMATO NETO, V.; MOREIRA, A.A.B.; CAMPOS, R. 1983. Pesquisa de anticorpos heterófilos no soro de indivíduos com doença de Chagas. Rev. Goiana Med., 29 :1-7.

PELlegriNo, J., 1953. A doença de Chagas em Minas Gerais. Esboço crítico dos trabalhos publicados até 1951. Mem. Inst. Oswaldo Cruz, $51: 611-668$.

RABINOVICH, J.E. \& ROSSELL, O., 1975. Mathematical models and ecology of Chaga' disease. In: PAHO, American Trypanosomiasis Research. Sc. Pub. 318, Washington:359-369.

RASSI, A., 1979. Clínica: fase aguda. In: Brener, Z. \& Andrade, Z. Trypanosoma cruzi e Doença de Chagas. Guanabara Koogan Ed., Rio de Janeiro :249-264.

RASSI, A. \& CARNEIRO, O., 1968. Alterações circulatórias na fase aguda da doença de Chagas. In:Cançado, J.R. Doença de Chagas. Imprensa Oficial, Minas Gerais :374-392.

ROMAÑ A, C., 1935. Acerca de un sintoma inicial de valor para el diagnóstico de forma aguda de la enfermedad de Chagas (la conjuntivitis esquizotripanósica unilateral). MEPR A, $22: 16-28$.

ROSSELL, O.J.R., 1976. Evaluación de la transmision de la enfermedad de Chagas en dos caserios del Estado Guarico /Venezuela) sometidos a rociamentos. Tese. Univ. Los Andes, Venezuela, 76 pp.

SCHLEMPER, JR., B.R., 1982. Caracterização de cepas do Trypanosoma cruzi isoladas de pacientes com diferentes formas clínicas da doença de Chagas. Tese. Dep. Med. Prev./Fac. Med. da Univ. Fed. do Rio de Janeiro, 130 pp..

SEGURA, L.E.; ABR AMO ORREGO, L.; ALVAREZ, M.; BENITEZ, J.L.; BENITEZ, H.; CAZZULO, J.J.; DE RISSIO, A.M.: DEL PRADO, C.F.; FAYAT, M.C.R.; JAUREGUI, N.; LAUSETTI, J.C.; MARTINI, G.J.W.; MORENO, M. PEREZ, A.; LUIZ, A. 1981 . Diagnóstico de laboratorio de la enfermedad de Chagas. Buenos Aires. Min. Salud. Inst. "Fatala Chaben", 45 pp.

SILVEIRA, A.C. \& SAKAMOTO, T, 1983. Importância médico-social da doença de Chagas no Brasil e de seu controle. Rev. Bras. Malariol. D. Trop., $35: 127-134$.

TAFURI, W.L., 1974. Alteraçôes ultra estruturais dos componentes muscular, intersticial e nervoso do coraçāo, esôfago e intestinos na doenf̧a de Chagas experimental e humana. Tese. Univ. Fed. Minas Gerais, Belo Horizonte.

TALICE, R.; COSTA, R.S.; RIAL, B. \& OSIMANI, J.J., 1940. Enfermedad de Chagas en el Uruguay. Monogr. Inst. Hig. Faclt. Med. Montevideo, Monteverde Ed., Montevideo, 349 pp.

TEIXEIRA, A.R.L., 1981. Competência imunológica do paciente chagásico. Imunodepressão na forma aguda inaparente. Auto-imunidade no hospedeiro imunizado. Tese. Curso Anatomia Patológica. Fac. Med./UFMG, Belo Horizonte, 169 pp.

TElXEIRA, M.G.L.C., 1977. Doença de Chagas. Estudo da forma aguda inaparente. Tese. Curso Doenças Infectuosas e Parasitárias. Fac. Med./UFRJ, Rio de Janeiro, 51 pp.

VATTUONE, H.N. \& YANOWSKY, J.F., 1971. Trypanosoma cruzi: agglutination activity of enzyme treated epimastigotes. Exp. Parasit., $30: 349-355$. 